\title{
Pengaruh Model Pembelajaran Kooperatif Tipe Talking Stick Terhadap Hasil Belajar Siswa Pada Pembelajaran Tematik Kelas V Sekolah Dasar Negeri Kota Bengkulu
}

\author{
Sakinah Gita Utami \\ Universitas Bengkulu \\ utamisakinahgita@yahoo.com \\ Nani Yuliantini \\ Universitas Bengkulu \\ Hasnawati \\ Universitas Bengkulu
}

\begin{abstract}
This research to determine the effect of the Talking Stick Cooperative Learning Model on Student Learning Outcomes in Thematic Learning Class V of Bengkulu City Primary School. Types of research is quantitative. Research method is experimental. The design in this study is "The Matching Only Pretest-Posttest Control Group Design". Population in this study is all students class V of elementary school Bengkulu City that applies the 2013 curriculum and accreditation A. The study sample was taken using the Random Sampling Cluster technique, so that the VA class SDN 71 Bengkulu city was obtained ad an experimental class and the VA Class SDN 103 Bengkulu city as control class. The research instrument used in the form of cognitive learning test result in the form of multiple choice provided through pretest and posttest in the experimental class and the control class. Data analysis technique in this research is quantitative analysis using descriptive statistics and infertial statistics. From the result of the study note the result of the t-test obtained tcound of Indonesian subjects at 4.37 and on natural science subjects at 4.81 with a ttable at a significant level of $5 \%$ of 2.00 where tcount is greater than ttable. From these data in appears that there are differences in learning outcomes achieved by student in the experimental and control classes. Thus it can be concluded that there is a significant effect on student learning outcomes in Thematic learning that uses the Talking Stick type of cooperative learning model.
\end{abstract}





\section{Keywords : Thematic Learning, Talking Stick Model, and Learning \\ Outcomes}

\section{Pendahuluan}

Kurikulum pada pembelajaran di tingkat SD dilaksanakan melalui pembelajaran Tematik. Menurut Winarni (2018:7) pada pembelajaran tematik akan lebih menekankan pada penerapan konsep belajar sambil melaksanakan sesuatu. Oleh karena itu, dengan guru merancang pengalaman siswa maka akan mempengaruhi kebermaknaan belajar siswa.

Pembelajaran tematik merupakan pembelajaran yang menekankan guru untuk mengaitkan dari satu mata pelajaran dengan mata pelajaran lainnya dengan bahan ajar. Menurut Halimah (2017:275) pembelajaran tematik adalah model pembelajaran terpadu yang menggunakan tema yang dikaitkan dengan beberapa mata pelajaran sehingga mampu memberikan pengalaman bagi peserta didik.

Pada pembelajaran tematik guru mampu mengaitkan bahan ajar siswa dari satu mata pelajaran dengan mata pelajaran lainnya dengan menggunakan tema yang ada. Dalam pembelajaran tematik siswa diharapkan dapat mendapatkan pengalaman yang bermakna dalam setiap pembelajaran karena di dalam pembelajaran tematik siswa akan dituntut untuk lebih aktif dalam proses pembelajaran. Menurut Rusman (2010:257) pembelajaran tematik lebih melibatkan siswa dalam proses belajar atau mengarahkan siswa secara aktif terlibat dalam proses pembelajaran. Melalui pembelajaran tematik siswa mampu memperoleh pengalaman langsung dan terlatih untuk menemukan sendiri pengetahuan yang dipelajari secara holistic, bermakna, auntentik dan aktif. Cara pengemasan pengalaman belajar yang dirancang guru sangat berpengaruh terhadap kebermaknaan belajar siswa.

Permasalahan pembelajaran tematik yang terjadi pada saat observasi ketika magang II disebabkan karena guru belum optimal menggunakan variasi metode, teknik, pendekatan dan konsep dalam kegiatan pembelajaran. Guru belum optimal menerapkan model pembelajaran yang efektif dan masih mengandalkan metode pembelajaran yang monoton seperti menghapal, mengandalkan materi yang ada di buku siswa dan guru tidak melibatkan untuk aktif dalam kegiatan pembelajaran sehingga siswa cepat bosan, tidak aktif dan enggan untuk memperhatikan penjelasan guru. Siswa juga banyak yang asik bermain sendiri, rebut bersama teman, bahkan tidur dikelas karena kurangnya inovasi dalam pemilihan metode pembelajaran, teknik mengajar, media pembelajaran, sumber belajar dan model pembelajaran yang diterapkan di kelas. Sebagian siswa masih kurang percaya diri untuk menyampaikan pendapat, tidak mau bekerja sama dengan teman dan tidak peduli dengan keadaan sosial saat proses pembelajaran. Menurut Muhith (2018) juga menambahkan permasalahan pembelajaran tematik yaitu bahwa guru belum sepenuhnya professional, siswa kurang bisa memahami materi yang disampaikan, kegiatan pembelajaran belum sepenuhnya sesuai dengan teori pelaksanaan pembelajaran tematik terpadu. 
Hal di atas berpengaruh terhadap hasil belajar siswa, maka untuk mengatasi permasalahan tersbeut, guru harus dapat merancang model pembelajaran yang bisa menarik perhatian siswa untuk belajar dan membuat siswa menjadi lebih aktif. Sehingga dapat memepengaruhi hasil belajar siswa. Salah satu upaya yang dapat digunakan untuk mengatasi permasalahan tersebut dengan menggunakan model pembelajaran yang efektif. Hal tersebut dipertegas oleh Marhaeni (2013) bahwa penggunaan model pembelajaran dapat berpengaruh terhadap hasil belajar siswa.

Salah satu model pembelajaran alternatif yang bisa dilakukan oleh guru agar siswa dapat berperan aktif dalam pembelajaran adalah dengan menerapkan model pembelajaran Talking Stick. Dalam melaksanakan proses pembelajaran harus menggunakan langkah-langkah yang sistematis untuk mencapai tujuan yang telah ditentukan. Dengan menggunakan model tersebut diharapkan dapat mempengaruhi hasil belajar peserta didik pada mata pelajaran.

Model pembelajaran Talking Stick adalah suatu model pembelajaran secara kelompok dengan menggunakan tongkat, sebelumnya siswa akan diberi waktu untuk mengingat materi pembelajaran kemudian akan diberikan pertanyaan bagi siswa yang memegang tongkat terakhir. Kegiatan tersebut terus diulangi sampai semua siswa mendapat giliran untuk menjawab pertanyaan yang diajukan oleh guru. Menurut Lestari, dll (2015:7) Talking Stick adalah model pembelajaran dengan bantuan tongkat dan musik pengiring, siswa yang memegang tongkat saat music berhenti dimainkan harus menjawab pertanyaan yang diajukan, demikian seterusnya.

Alasan peneliti memilih model pembelajaran ini karena dengan menerapkan model ini siswa secara keseluruhan dapat berperan aktif dalam pembelajaran dan dapat meningkatkan aktivitas belajar siswa. Model Talking Stick ini melatih siswa untu siap menerima soal dan menjawabnya dengan benar. Dari kesigapan siswa menerima soal membuat semua siswa menjadi aktif dan mudah untuk menerima materi pembelajaran. Dengan menerapkan model Talking Stick ini diharapkan dapat memudahkan proses pembelajaran dan dapat membuat selurug siswa berperan aktif sehingga mengatasi rendahnya hasil belajar siswa pada pembelajaran tematik. Dalam menggunakan model Talking Stick ini juga diperkuat oleh hasil dari penelitian Siregar (2015) yang mengatakan bahwa yang mempengaruhi aktivitas belajar siswa dengan menggunakan Talking Stick tersebut membuat siswa lebih bersemangat dan lebih cepat mengerti, serta membuat suasana belajar yang menyenangkan sehingga siswa aktif, dalam proses pembelajaran terlihat suasana lebih hidup dikarenaka siswa lebih antusias dan siap menerima pembelajaran.

Menurut hasil penelitian Andriyani (2017), di SD Negeri 1 Palapa tentang "Pengaruh Penggunaan Model Pembelajaran Talking Stick Terhadap Hasil Belajar Siswa Pada Pembelajaran Terpadu Kelas IV SD Negeri 1 Palapa”, yang menunjukkan bahwa model Talking Stick bisa meningkatkan hasil belajar tematik siswa sekolah dasar. Pengarunya dapat dilihat dari nilai rata-rata hasil belajar siswa yang mengikuti pembelajaran menggunakan model pembelajaran kooperatif tipe Talking Stick lebih tinggi dibandingakan dengan nilai rata-rata hasil belajar siswa yang melaksanakan pembelajaran tanpa menerapkan model pembelajaran talking stick. Berdasarkan permasalahan di atas peneliti tertarik melakukan penelitian yang berjudul "Pengaruh Model Pembelajaran Kooperatif Tipe Talking Stick 
Terhadap Hasil Belajar Siswa Pada Pembelajaran Tematik Kelas V Sekolah Dasar Negeri Kota Bengkulu".

\section{Metode}

Penelitian ini adalah penelitian kuantitaif dengan menggunakan metode eksperimen. Metode penelitian eksperimen yang digunakan adalah quasi eksperiment (eksperimen semu). Desain dalam penelitian ini adalah The Matching Only Pretest-posttest Grup Design. Desain ini membutuhkan dua kelompok subjek yang kemudian dipilih secara acak dalam kelompok tersebut. Selanutnya tiap kelompok akan diberikan tes sebanyak dua kali yaitu Pretest dan Posttest.

Sugiyono (2017:8) menyatakan bahwa populasi merupakan subjek/objek yang terdapat karakteristik tertentu yang ditetapkan oleh peneliti untuk dipelajari dan kemudian ditarik kesimpulannya. Adapun populasi dalam penelitian ini adalah seluruh siswa kelas V SDN Kota Bengkulu yang menerapkan kurikulum 2013 dan berakreditasi A tahun ajaran 2019/2020 yang berjumlah 42 SD dari 81 SD Negeri dan dari 105 SD di Kota Bengkulu, baik sekolah negeri maupun sekolah swasta.

Sampel adalah bagian dari populasi. Winarni (2018:40) sampel merupakan himpunan dari bagian suatu populasi. Dalam menetukan sampel penelitian terdapat dua teknik sampling, yaitu random sampling dan non-random sampling. Penelitian ini menentukan kelas eksperimen dan kontrol dengan menggunakan teknik random sampling yaitu Cluster random sampling yang merupakan pengacakan sampel kelompok.

Cara peneliti untuk mengambil sampel dengan melakukan pengacakan Rombel (Rombongan Belajar) dari 42 SD tersebut. Hasil pengacakan didapat kelas VA SDN 71 Kota Bengkulu sebagai kelas eksperimen yang berjumlah 30 siswa dan kelas VA SDN 103 Kota Bengkulu sebagai kelas kontrol yang berjumlah 30 siswa.

\section{Hasil}

Hasil penelitian diperoleh melalui pembelajaran Tematik teme 6 (Panas dan Perpindahanya), subtema 3 (Pengaruh Kalor Terhadap Kehidupan, Pembelajaran 1 dengan mata pelajaran Bahasa Indonesia dan IPA. Penelitian ini bertujuan untuk mengetahui pengaruh model pembelajaran kooperatif tipe Talking Stick terhadap hasil belajar siswa pada pembelajaran tematik di kelas V SD Negeri Kota Bengkulu.

Adapun nilai rata-rata pretest yang diperoleh pada kelas eksperimen pada mata pelajaran Bahasa Indonesia sebesar 48,68 dan kelas kontrol untuk mata pelajaran Bahasa Indonesai sebesar 46,00. Rata-rata yang diperoleh pada kelas eksperimen pada mata pelajaran IPA sebesar 44,67 dan kelas kontrol untuk mata pelajaran IPA sebesar 43,67. Dilihat dari nilai rata-rata hasil yang diperoleh siswa pada kelas eksperimen dan kealas kontrol untuk mata pelajaran Bahasa Indonesia dan IPA tidak ada perbedaan yang signifikan pada nilai rata-rata pretest.

Setelah melakukan uji normalitas kedua sampel, selanjutnya akan dilakukan uji homogenitas menggunakan uji varian. Berdasarkan data hasil perhitungan nilai f fitung pretest mata pelajaran Bahasa Indonesia sebesar 1,19 lebih kecil daripada nilai $f_{\text {tabel }}$ pada tarag signifikan $5 \%$ sebesar 1,86 . Artinya status varian 
pretest mata pelajaran Bahasa Indonesia kelas eksperimen dan kelas kontrol berasal dari varian yanh homogen. Nilai f fitung pretest mata pelajaran IPA sebesar 0,88 lebih kecil daripada $f_{\text {tabel }}$ pada taraf signifikan $5 \%$ sebesar 1,86 . Artinya status varian pretetst mata pelejaran IPA kelas eksperimen dank e; as kontrol berasal dari varian yang homogen.

Langkah terakhir dilakukan dengan analisis statistic inferensial. Pengujian hipotesis penelitian yang dilakukan dengan menggunakan uji-t. Uji-t dilakukan untuk menguji pengaruh penggunaan model pembelajaran kooperatif tipe Talking Stick terhadap hasil belajar siswa pada aspek pengetahuan. Apabila $t_{\text {hitung }}<\mathrm{t}_{\text {tabel }}$ berarti tidak terdapat perbedaan rata-rata hasil belajar pretest aspek pengetahuan siswa antara kelas eksperimen dan kelas kontrol. Berdasarkan data hasil perhitungan menunjukan bahwa nilai $t_{\text {tabel }}$ pretest mata pelajaran Bahasa Indonesia adalah $1,25<$ t tabel pada taraf signifikan $5 \%$ sebesar 2,00 . Pada pretest mata pelajaran IPA nilai thitung adalah 0,06 $<t_{\text {tabel }}$ padataraf signifikan 5\% sebesar 2,00. Untuk thitun pretest kedua mata pelajaran Bahasa Indonesia dan IPA berada di daerah penerimaan $\mathrm{H} 0$ dan penolakan Ha. Artinya tidak terdapat perbedaan kemampuan awal siswa pada kelas eksperimen dan kelas kontrol atau kemampuan awal mereka sama,

Adapun nilai rata-rata posttest mata pelajaran Bahasa Indonesia pada kelas eksperimen sebesar 74,33 dan pada kelas kontrol diperoleh nilai rata-rata sebesar 74,33 dan pada kelas kontrol diperoleh nilai rata-rata sebesar 57,33. Perbedaan nilai rata-rata mata pelajaran Bahasa Indonesia kelas eksperimen dan kontrol adalah sebesar 17,00. Sedangkan nilai rata-rata yang diperoleh mata pelajaran IPA pada kelas eksperimen sebesar 74,33 dan pada kelas kontrol diperoleh nilai rata-rata sebesar 55,00. Perbedaan nilai rata-rata mata pelajaran IPA kelas eksperimen dan kelas kontrol adalah sebesar 18,33. Dari data tersebut terdapat perbedaan yang signifikan untuk rata-rata nilai yang diperoleh siswa pada mata pelajaran Bahasa Indonesia dan IPA pada pelaksanaan posttest.

Setelah melakukan uji normalitas, selanjutnya kedua sampel akandilakukan uji homogenitas menggunakan uji $\mathrm{F}$. sampel bisa dikatakan memiliki varian homogen apabila $f_{\text {hitung }}$ lebih kecil daripada $f_{\text {tabel }}$ pada taraf signifikan $5 \%$. Berdasarkan hasil posttest Bahasa Indonesia dan IPA menunjukan bahwa nilai $f_{\text {hitung }}$ mata pelajaran Bahasa Indonesai sebesar 0,45 lebih kecil daripada nilai $f_{\text {tabel }}$ pada taraf signifikan 5\% sebesar 1,86. Artinya status varian posttest mata pelajaran Bahasa Indonesia kelas eksperimen dan kelas kontrol dari varian yang homogen. Adapun nilai fhitung posttest mata pelajaran IPA sebesar 1,54 lebih kecil daripada nilai $\mathrm{f}_{\text {tabel }}$ pada taraf signifikan $5 \%$ sebesar 1,86 . Artinya status varian posttest mata pelajaran IPA kelas eksperimen dan kelas kontrol berasal dari varian yang homogen.

Berdasarkan pengujian data di atas diketahui bahwa dari kedua sampel berdistribusi normal dan homogen, maka pengujian ini menggunakan uji parametrik dengan menggunakan uji-t. dalam perhitungan uji-t apabila thitung $<$ tabel berarti tidak terdapat perbedaan yang signifikan antara kelas eksperimen dan kelas kontrol dan sebaliknya jika thitung $>$ tabel berarti terdapat perbedaan signifikan antara kelas ekperimen dan kelas kontrol. Berdasarkan hasil uji-t menunjukan bahwa nilai thitung posttest mata pelajaran Bahasa Indonesai yaitu 4,37 > ttabel pada taraf signifikan 5\% sebesar 2,00. Pada posttest mata pelajaran IPA nilai thitung adalah $4,81>$ t tabel pada 
taraf signifikan $5 \%$ sebesar 2,00. Untuk thitung kedua mata pelajaran Bahasa Indonesia dan IPA berada di daerah penerimaan Ha. Sehingga dapat dikatakan bahwa terdapat pengaruh penggunaan model pembelajaran kooperatif tipe Talking Stick terhadap hasil belajar siswa pada pembelajaran Tematik kelas V Sekolah Dasar Negeri Kota Bengkulu.

Terdapat perbedaan signifikan hasil belajar aspek pengetahuan antara kelas eksperimen dan kelas kontrol, hal ini disebabkan adanya perbedaan perlakuan antara kelas eksperimen dan kelas kontrol yang menggunakan model pembelajaran kooperatif tipe Talking Stick, sedangkan pada kelas kontrol tidak menggunakan model pembelajaran atau pembelajaran konvensional. Sehingga dari rincian nilai rata-rata yang diraih siswa dapat dikatakan bahwa model pembelajaran kooperatof tipe Talking Stick berpengaruh terhadap hasil belajar siswa.

\section{Pembahasan}

Hasil analisis pretest menunjukkan tidak terdapat perbedaan signifikan kemampuan awal siswa antara kelas eksperimen dengan kelas kontrol. Sementara, hasil analisis posttest menunjukkan terdapat perbedaan signifikan antara kelas kelas eksperimen dengan kelas kontrol. Perbedaan tersebut dikarenakan adanya pemberian perlakuan berupa penggunaan model pembelajaran kooperatif tipe Talking Stick. Perbedaan hasil belajar menunjukan bahwa model pembelajaran kooperatif tipe Talking Stick berpengaruh terhadap hasil belajar siswa pada pembelajaran tematik di kelas V SD Negeri Kota Bengkulu. Hal ini terlihat dari hasil uji perbedaan pretest dan posttest yang menunjukkan hasil posttest lebih baik dibandingkan dengan hasil pretest.

Penggunaan model pembelajaran kooperatig tipe Talking Stick akan mengarahkan siswa untuk aktif, baik dalam berdiskusi dan tanya jawab, serta membuat proses pembelajaran lebih menyenangkan, dan siswa berani untuk mengemukakan pendapat. Sejalan dengan pendapat (Fajrin, 2018; Indriyani, Yuyarti,2015) bahwa model pembelajaran Talking Stick lebih menyenangkan dan membuat peserta didik aktif dibandingkan dengan menggunakan pembelajaran konvensional, dan dapat meningkatkan keterampilan, keaktifan dalam pembelajaran.

Setelah kegiatan pembelajaran dilakukan, maka diberikan lembar posttest pada kelas eksperimen dan kelas kontrol. Hasil posttest menunjukkan rata-rata nilai di kelas eksperimen untuk mata pelajaran Bahasa Indonesia sebesar 74,33 sedangkan pada kelas kontrol nilai rata-rata mata pelajaran Bahasa Indonesia sebesar 57,33. Untuk nilai rata-rata kelas eksperimen pelajaran IPA sebesar 74,33 sedangkan kelas kontrol untuk mata pelajaran IPA sebesar 56,00. Pada nilai posttest didapatkan bahwa thitung pada mata pelajaran Bahasa Indonesai sebesar 4,37 dan pada mata pelajaran IPA 4,81 lebih besar dibandingkan tabel $(2,00)$, artinya H0 ditolak dan Ha diterima.

Dengan demikian, dapat dikatakan bahwa model pembelajaran kooperatif tipe Talking Stick berpengaruh terhadap hasil belajar aspek pengetahuan siswa pada pembelajaran Tematik kelas V Sekolah Dasar Negeri Kota Bengkulu. Pengaruh model pembelajaran kopperatif tipe Talking Stick ditandai dengan nilai rata-rata 
posttest kelas eksperimen lebih besar dari kelas kontrol. Hal ini sejalan dengan hasil penelitian (Faradita,2017;Utama,dkk,2018)) yang menyatakan model pembelajaran kooperatif learning type Talking Stick dapat mempengaruhi peningkatan hasil belajar siswa pada mata pelajaran IPA dan PKN pada siswa Sekolah Dasar.

Dengan menggunakan model pembelajaran kooperatif tipe Talking Stick membuat siswa menjadi aktif dan terlibat langsung dalam proses pembelajaran. Hal ini dapat dilihat dari siswa lebih menghargai pendapat orang lain, percaya diri ketika berpendapat, dan bertanggung jawab dengan tugas yang diberikan. Hal ini sesuai dengan hasil penelitian yang dilakukan (Pour, dkk, 2018; Utami,2014) menyatakan bahwa dengan menerapkan model pembelajaran Talking Stick pada pembelajaran dapat memberikan pengaruh baik pada keaktifan belajar siswa dan dapat meningkatkan keaktifan siswa dalam pembelajaran.

\section{Simpulan}

Berdasarkan hasil dan pembahasan penelitian pada pembelajaran Tematik dengan muatan mata pelajaran Bahasa Indonesai dan IPA mengenai pengaruh penerapan kooperatif tipe Talking Stick terhadap hasil belajar siswa pada pembelajaran Tematik siswa kelas V Sekolah Dasar Negeri Kota Bengkulu, didapatkan untuk hasil belajar aspek pengetahuan hasil uji t-hipotesis pada posttest kelas eksperimen thitung lebih besar dari tabel. Dengan nilai pada mata pelajaran Bahasa Indonesia thitung $(4,37)>t_{\text {tabel }}(2,00)$, dan pada mata pelajaran IPA thitung $(4,81)$ $>$ tabel $(2,00)$, sehingga dapat disimpulkan bahwa terdapat pengaruh penggunaan model pembelajaran kooperatif tipe Taling Stick terhadap hasil belajar siswa pada pembelajaran Tematik kelas V Sekolah Dasar Negeri Kota Bengkulu.

\section{Saran}

Berdasarkan hasil penelitian yang telah dilakukan, maka peneliti memberikan saran:

1. Guru lebih memperhatikan alokasi waktu yang dibutuhkan sesuai dengan materi yang akan disampaikan.

2. Dalam memberikan bimbingan selama proses pembelajaran, guru sebaiknya memperhatikan tiap individu dalam kelompok terutama saat kegiatan diskusi dan menjawab pertanyaan. Hal ini bertujuan agar siswa dapat mengikuti proses pembelajaran dengan baik sehingga tidak mengalami ketertinggalan terutama saat diskusi dan menjawab soal pertanyaan.

3. Guru lebih tau cara mengendalikan siswa saat memutar tongkat sehingga kelas tetap kondusif.

\section{Referensi}

Andriyani, et al., (2017) Pengaruh Penggunaan Model Pembelajaran Talking Stick Terhadap Hasil Belajar Siswa Pada Pembelajaran Terpadu Kelas IV SD Negeri 1 Palapa, Jurnal Ilmu Pendidikan FKIP Univ.Lampung Tersedia : https://www.google.com/url?sa=t\&rct=i\&q=\&esrc=s\&source=web\&cd=1\&cad= rja\&uact=8\&ved=2ahUKEwjhiKmXue7nAhXVmeYKHXA8CQgQFjAAegQIB hAB\&url=http\%3A\%2F\%2Fjurnal.fkip.unila.ac.id\%2Findex.php\%2Fpgsd\%2F 
article\%2FdownloadSuppFile\%2F14718\%2F2286\&usg=AOvVaw2k242i5Vu-

YSBPzaRudTnc

diunduh pada tanggal : 11 November 2019

Fajrin, Oktaviastuti (2018). Pengaruh Model Talking Stick Terhadap Hasil Belajar IPS Siswa SD. Jurnal Bidang Pendidikan Dasar (JBPD), Vol 2 No, 1A April 2018

Tersedia :

https://www.researchgate.net/publication/328131603_Pengaruh_Model_Talki

ng_Stick_terhadap_Hasil_Belajar_IPS_Siswa_SD

Diunduh pada tanggal : 24 Februari 2020

Faradita, Nanda (2018), Pengaruh Metode Pembelajaran type Talking Stick Terhadap Hasil Belajar Siswa IPA pada Siswa Kelas 4 Sekolah Dasar, Jurnal Bidang Pendidikan Dasar (JBPD), Vol. 2 No. 1A April 2018

Tersedia :

http://ejournal.unikama.ac.id/index.php/JBPD

diunduh pada tanggal : 1 Maret 2020

Halimah, Leli (2017), Keterampilan Mengajar. Bandung : PT. Refika Aditama

Indriyani,Yuyarti (2015), Peningkatan Kualitas Pembelajaran PKN Melalui Model Talking Stick Berbantuan Media Audiovisual, Joyful Learning Jurnal.

Tersedia :

https://journal.unnes.ac.id/sju/index.php/jlj/article/view/8402/5641

Diunduh pada tanggal : 07 Maret 2020

Lestari, Karunia Eka (2015), Penelitian Pendidikan Matematika. Bandung : PT Refika Aditama

Marhaeni, et al., (2013) Pengaruh Implementasi Pembelajaran Tematik Terhadap Prestasi Belajar Ditinjau Dari Motivasi Belajar Pada Siswa Kelas IV Gugus Empat di Kecamatan Gianyar, e-Journal Program Pascasarjana Universitas Pendidikan Ganesha Program Studi Penelitian dan Evaluasi Pendidikan.

Tersedia :

https://media.neliti.com/media/publications/207601-pengaruh-implementasipembelajaran-temat.pdf

Diunduh pada tanggal : 03 Februari 2020

Muhith, (2018) Problematika Pembelajaran Tematik Terpadu di MIN III Bondowoso, Indonesian Journal of Islamic Teaching

Tersedia :

http://digilib.iain-jember.ac.id/380/

Diunduh pada tanggal : 02 Februari 2020

Pour, et al., (2018), Pengaruh Model Pembelajaran Talking Stick Terhadap Keaktifan Belajar Siswa, Jurnal Penelitian dan Pengkajian Ilmu Pendidikan: e-saintika Tersedia :

https://media.neliti.com/media/publications/287946-pengaruh-model-

pembelajaran-talking-stic-528a1289.pdf

Diunduh pada tanggal : 23 Februari 2020

Rusman (2010), Model-model Pembelajaran, Jakarta : PT. Raja Grafindo Persada

Siregar (2015), Pengaruh Model Pembelajaran Talking Stick Terhadap Hasil Belajar dan Aktivitas Visual Siswa pada Konsep Sistem Indra, Jurnal Biotik

Tersedia :

https://jurnal.ar-raniry.ac.id/index.php/biotik/article/view/999

Diunduh pada tanggal : 02 Februari 2020

Sugiyono (2017), Metode Penelitian Pendidikan. Bandung : Alfabeta

Utama,dkk (2018), Pengaruh Model Talking Stick Terhadap Hasil Belajar PKN Pada

Siswa Kelas V Semester II SD di Gugus 1 Kecamatan Gerokgak, Jurnal Imiah Pendidikan dan Pembelajaran

Tersedia :

https://ejournal.undiksha.ac.id/index.php/JIPP/article/download/15405/9412

Diunduh pada tanggal : 7 Maret 2020 
Utami (2014), Penerapan Metode Talking Stick untuk Meningkatkan Keaktifan Siswa dalam Pembelajaran IPA pada Siswa Kelas 1 SD Negeri 1 Katong, Toroh, Kabupaten Grobogan, Jurnal Imiah Pendidikan dan Pembelajaran Tersedia :

http://eprints.ums.ac.id/29147/9/Naskah_Publikasi_Ilmiah.pdf Diunduh pada tanggal : 7 Maret 2020

Winarni, Endang Widi (2018), Pendekatan Ilmiah Dalam Pembelajaran Kreatif dan Inovatif. Bengkulu : Unit Penerbitan FKIP UNIB 